\title{
Properties and clinical implications of body mass indices
}

\author{
K P Fung, J Lee, S P Lau, O K W Chow, $\mathrm{T} W$ Wong, D P Davis
}

\begin{abstract}
The properties of body mass indices were evaluated in a cross sectional study of the weights and heights of 5016 Chinese boys and girls aged between 3 and 18 years. Of the indices examined (weight/height $(\mathrm{W} / \mathrm{H})$, weight/height ${ }^{2}\left(W / H^{2}\right)$, weight/height ${ }^{3}\left(W / H^{3}\right)$ and weight/height $\left.{ }^{\mathrm{p}}\left(\mathbf{W} / \mathbf{H}^{\mathrm{p}}\right)\right), W / \mathbf{H}^{\mathrm{p}}$ was the only one that consistently showed least correlation with height, and so could be regarded as the optimal body mass index by the criterion of indepence of the index from height. The exponent ' $p$ ' of $W / H^{p}$ is, however, highly dependent on age; the value increases steadily between the age of 3 and 7-9 years, and then varies considerably around puberty. Only the age specific exponent ensures a lack of correlation between body mass index $\left(W / H^{P}\right)$ and height. Age specific $W / H^{p}$ should therefore be used in intrapopulation studies of weight or problems associated with obesity in children. Interpopulation comparison of weight and adiposity by $W / H, W / H^{2}$, or $W / H^{3}$ may give misleading results because of their dependence on height. Our results also suggest that the conventional weight for height charts may not be accurate enough for clinical use.
\end{abstract}

Department of Paediatrics, National University Hospital, National University of Singapore,

Lower Kent Ridge Road, Republic of Singapore

0511

K P Fung

Department of

Community,

Occupational,

and Family Medicine,

National University

of Singapore

J Lee

Department of

Paediatrics,

University of Hong Kong

$S$ P Lau

$\mathrm{O} \mathrm{K}$ W Chow

Department of

Community Medicine,

Chinese University

of Hong Kong

$T$ W Wong

Department of

Paediatrics,

Chinese University

of Hong Kong

D P Davis

Correspondence to:

Dr Lee.

Accepted 18 November 1989
Weight for height indices (body mass indices) have been extensively used as indirect measures of obesity to study the nutritional state of children and the epidemiology of diseases associated with obesity. Derived solely from measurements of weight and height, the optimal body mass index should correlate most accurately with weight and adiposity, and be only minimally biased by height. ${ }^{1}$ The latter assumption is justified by the independency of adiposity to height. ${ }^{2-4}$ Despite their high intercorrelations and similar correlations with weight and adiposity, ${ }^{5-7}$ traditional body mass indices (weight/height $(\mathrm{W} / \mathrm{H})$, weight/height ${ }^{2}\left(\mathrm{~W} / \mathrm{H}^{2}\right)$, weight $/$ height $^{3}\left(\mathrm{~W} / \mathrm{H}^{3}\right)$ and weight/height ${ }^{\mathrm{p}}$ $\left(\mathrm{W} / \mathbf{H}^{\mathrm{p}}\right)$ ) do not seem to be interchangeable in exploring associations between obesity and disease $^{8}$ and the incidence of obesity. ${ }^{910}$ Indiscriminate use of body mass indices may result in contradictory clinical inferences. For equal correlations with adiposity and body weight, it is probable that the best body mass index would be the one that was the least dependent on height; this can be found by calculating the best exponent ' $\mathrm{p}$ ' for Benn's index $\left(\mathrm{W} / \mathrm{H}^{\mathrm{p}}\right) .{ }^{11}$ In heterogeneous adult populations, ' $p$ ' is usually close to 2 , and therefore $W / H^{2}$ has been consistently recommended as the power index. ${ }^{3-5}$ In children, however, ' $p$ ' is expected to vary when tissue composition and body frame change rapidly during growth and puberty. We studied the serial change in the exponent of Benn's index $\left(\mathrm{W} / \mathrm{H}^{\mathrm{p}}\right)$ from childhood to adulthood so that we could compare the properties of the different body mass indices and discuss the clinical implications.

\section{Patients and methods}

A total of 2480 boys and 2536 girls aged from 3 to 18 years were recruited from five schools and four kindergartens between 1984 and 1986. These institutes were located in different areas of Hong Kong. All children belonging to randomly selected classes were studied. Essentially, therefore, our subjects represented an even social class distribution of Hong Kong. Children who had had recent acute or chronic illnesses, as well as those with obvious dysmorphic features and skeletal deformities, were excluded. ${ }^{12} 13$ Standing height was measured with a Harpenden stadiometer to the nearest $\mathrm{mm},{ }^{14}$ and body weight was recorded on a calibrated scale to the nearest $50 \mathrm{~g}$ for children under 7 years old, and the nearest $0.2 \mathrm{~kg}$ for older children. Children were measured and weighed without shoes and in standard light summer uniform (which weighed $<0.2 \mathrm{~kg}$ ). Decimal age was calculated from the date of birth and the date of examination.

\section{STATISTICAL METHOD}

Body mass indices were computed separately for boys and girls, who were divided into age groups in yearly intervals from 3 to 17 years, as well as for all age groups combined. $W / H$, $\mathrm{W} / \mathrm{H}^{2}$, and $\mathrm{W} / \mathrm{H}^{3}$ were calculated directly from weight $(\mathrm{kg})$ and height $(\mathrm{cm})$. The exponent ' $p$ ' of Benn's index $\left(W / H^{p}\right)$ and their standard errors (SE) for each age specific group and the overall age groups were computed in two different ways: firstly, more accurately, as the slope of the linear regression of logarithmic transformed weights and heights and, secondly, as $\beta \times$ mean height/mean weight according to Benn's approximation principle, where $\beta$ is the slope of the linear regression of weight on height for the individual groups concerned. ${ }^{11}$ The linear regression was weighted against the reciprocal of $\mathrm{W}^{2}$ because of heterogeneity of variance. ${ }^{15}$ The non-parametric Spearman rank method was used to correlate the derived body mass indices with the heights, because the measurements of height were not normally distributed. The $\chi^{2}$ test was used to assess the signficance of differences between groups. 
Results

The exponents ( $\mathrm{p}$ ) of $\mathrm{W} / \mathrm{H}^{\mathrm{p}}$ derived by logarithmic regression are comparable with those approximated by weighted linear regression for age specific and all age groups from the age of 3 to 6 years (table 1). Their values rise steadily until the age of 6 years; they then climb rapidly and peak at the age of 9 years $\left(p^{\prime}=3 \cdot 81\right)$ for boys and 7 years $\left(p^{\prime}=2.98\right)$ for girls. They peak again at the age of 11 years for both sexes before they decline to much lower values. The exponents for children older than 6 , and for overall age groups estimated by Benn's modified approximation method, deviate significantly from those calculated by logarithmic linear regression.

In the age specific groups (table 2), Spearman rank correlation coefficients (in absolute values) that relate body mass index to standing height, rank highest for $W / H$, followed by $W / H^{2}$, and finally by $\mathrm{W} / \mathrm{H}^{3}$ for groups at the age between around 7 to 13 years. The reverse is the case outside this age range. Age specific $\mathrm{W} / \mathrm{H}^{\mathrm{p}}$ is the only body mass index that consistently fails to correlate with height. When the slope $\beta$ of the logarithmic linear regression $(\log W$ on $\log \mathrm{H})$ for the overall sex specific group is used as the exponent of $W / H^{p} \quad(p=\beta)$, the correlation between this body mass index and height in age specific groups becomes highly unpredictable and inconsistent (table 2). The absolute rank correlation coefficients vary between a negli- gible 0.0019 and a highly significant 0.39 $(p=0.0003)$. When all age groups are pooled, however, all the body mass indices (including $\mathrm{W} / \mathrm{H}^{\mathrm{p}}$, , table 2 ) are significantly dependent on height. The age dependent properties of body mass indices are similar in boys and girls.

\section{Discussion}

The dependency of ' $p$ ' on age in children has not been studied thoroughly. Dugdale proposed $\mathrm{W} / \mathrm{H}^{1.6}$ and $\mathrm{W} / \mathrm{H}^{2.42}$ as age independent nutrition indices for children above and below 5 years old, respectively. ${ }^{1016}$ Cole has shown that 'p' rises from the age of 5 to 12 years by differentiating the National Center for Health Statistics (NCHS) median standard weight/height curves plotted against age. ${ }^{17}$ The 'p' computed by this method, which ignores the data distribution and heterogeneity of variance in age specific subgroups, is not quite independent of height. ${ }^{11}$ Our data have shown that the exponent of $W / H^{p}$ changes substantially with age. Although ' $p$ ' increases steadily in early childhood, its value around puberty becomes highly variable, and probably does not follow any pattern. Cole has recently observed that the ' $p$ ' for white boys peaks around the age of 11 , about 18 months later than that of girls. The difference in the timing of spurts between the boys and girls has been attributed to the earlier occurrence of puberty in girls. ${ }^{18}$ Such a

Table 1 Exponents for the $W / H^{p}$ body mass index and their standard errors

\begin{tabular}{|c|c|c|c|c|c|c|}
\hline \multirow[b]{2}{*}{ Age (years) } & \multicolumn{3}{|l|}{ Boys } & \multicolumn{2}{|l|}{ Girls } & \multirow[b]{2}{*}{$p(S E)$} \\
\hline & No of subjects & $p^{\prime}(S E)$ & $p(S E)$ & No of subjects & $p^{\prime}(S E)$ & \\
\hline $\begin{array}{r}3 \\
4 \\
5 \\
6 \\
7 \\
8 \\
9 \\
10 \\
11 \\
12 \\
13 \\
14 \\
15 \\
16 \\
17\end{array}$ & $\begin{array}{r}174 \\
328 \\
321 \\
438 \\
258 \\
117 \\
86 \\
88 \\
94 \\
98 \\
93 \\
88 \\
104 \\
98 \\
95\end{array}$ & $\begin{array}{l}2.29(0.13) \\
2.39(0.10) \\
2.67(0.12) \\
2.58(0.12) \\
2.87(0.17) \\
3.02(0.29) \\
3.81(0.30) \\
2.86(0.40) \\
3.48(0.37) \\
3.42(0.28) \\
2.79(0.29) \\
2.44(0.32) \\
2.91(0.34) \\
2.51(0.31) \\
1.28(0.41)\end{array}$ & $\begin{array}{l}2.22(0.14) \\
2.22(0.11) \\
2.44(0.13) \\
2.35(0.14) \\
2.52(0.20) \\
2.66(0.32) \\
3.36(0.34) \\
2.38(0.45) \\
2.92(0.42) \\
3.17(0.30) \\
2.42(0.35) \\
2.30(0.35) \\
2.60(0.37) \\
2.47(0.32) \\
1.50(0.35)\end{array}$ & $\begin{array}{r}169 \\
305 \\
304 \\
362 \\
269 \\
127 \\
92 \\
92 \\
100 \\
120 \\
119 \\
122 \\
131 \\
112 \\
112\end{array}$ & $\begin{array}{l}2.05(0.14) \\
2.15(0.10) \\
2.57(0.13) \\
2.67(0.13) \\
2.98(0.16) \\
2.77(0.23) \\
2.66(0.22) \\
2.91(0.33) \\
3.19(0.31) \\
2.87(0.31) \\
2.53(0.31) \\
1.92(0.36) \\
1.05(0.24) \\
2.01(0.35) \\
1.96(0.33)\end{array}$ & $\begin{array}{l}2.00(0.14) \\
2.06(0.10) \\
2.43(0.14) \\
2.51(0.15) \\
2.69(0.17) \\
2.53(0.24) \\
2.39(0.24) \\
2.76(0.36) \\
3.23(0.31) \\
2.67(0.33) \\
2.35(0.34) \\
2.01(0.38) \\
1.05(0.27) \\
1.85(0.36) \\
1.80(0.35)\end{array}$ \\
\hline All ages & 2480 & $2.57(0.01)$ & $2.20(0.02)$ & 2536 & $2.64(0.02)$ & $2.21(0.02)$ \\
\hline
\end{tabular}

$\mathbf{p}^{\prime}=$ Exponent derived from logarithmic transformed linear regression. $\mathbf{p}=$ Exponent derived from weighted linear regression.

Table 2 Spearman rank correlation coefficients for body mass indices and standing height

\begin{tabular}{|c|c|c|c|c|c|c|c|c|c|c|}
\hline \multirow[b]{2}{*}{ Age (years) } & \multicolumn{5}{|l|}{ Boys } & \multirow{2}{*}{$\frac{\text { Girls }}{W / H^{p}}$} & \multirow[b]{2}{*}{$W / H$} & \multirow[b]{2}{*}{$W / H^{2}$} & \multirow[b]{2}{*}{$W / H^{3}$} & \multirow[b]{2}{*}{$W / H^{p \prime \prime}$} \\
\hline & $W / H^{p}$ & $W / H$ & $W / H^{2}$ & $W / H^{3}$ & $W / H^{p \prime \prime}$ & & & & & \\
\hline $\begin{array}{r}3 \\
4 \\
5 \\
6 \\
7 \\
7 \\
8 \\
9 \\
10 \\
11 \\
12 \\
13 \\
14 \\
15 \\
16 \\
17\end{array}$ & $\begin{array}{r}-0.03^{*} \\
-0.08^{*} \\
-0.12^{*} \\
-0.06^{*} \\
-0.11^{*} \\
-0.07^{*} \\
-0.06^{*} \\
-0.04^{*} \\
0.01^{*} \\
-0.02^{*} \\
-0.03^{*} \\
0.01^{*} \\
-0.05^{*} \\
0.00^{*} \\
-0.03^{*}\end{array}$ & $\begin{array}{l}0.53 \\
0.61 \\
0.61 \\
0.55 \\
0.53 \\
0.59 \\
0.76 \\
0.48 \\
0.59 \\
0.67 \\
0.60 \\
0.44 \\
0.43 \\
0.44 \\
0.17^{*}\end{array}$ & $\begin{array}{l}0.12^{*} \\
0.16 \\
0.23 \\
0.19 \\
0.23 \\
0.29 \\
0.58 \\
0.23 \\
0.36 \\
0.49 \\
0.33 \\
0.15^{*} \\
0.21 \\
0.15^{*} \\
-0.06^{*}\end{array}$ & $\begin{array}{c}-0.38 \\
-0.38^{*} \\
-0.26 \\
-0.23 \\
-0.15 \\
-0.06^{*} \\
0.24 \\
-0.06^{*} \\
0 \cdot 10^{*} \\
0 \cdot 14^{*} \\
-0.13^{*} \\
-0.16^{*} \\
-0.07^{*} \\
-0.16^{*} \\
-0.31\end{array}$ & $\begin{array}{c}-0.17 \\
-0.17 \\
-0.06 \\
-0.06^{*} \\
0.01^{*} \\
0.08^{*} \\
0.39 \\
0.04^{*} \\
0.21 \\
0.32 \\
0.06^{*} \\
-0.04^{*} \\
0.04^{*} \\
-0.02^{*} \\
-0.21\end{array}$ & $\begin{array}{r}0.02^{*} \\
-0.01^{*} \\
-0.02^{*} \\
-0.07^{*} \\
-0.02^{*} \\
-0.02^{*} \\
0.00^{*} \\
0.01^{*} \\
0.02^{*} \\
-0.01^{*} \\
0.02^{*} \\
0.00^{*} \\
0.14^{*} \\
-0.05^{*} \\
-0.02^{*}\end{array}$ & $\begin{array}{l}0.47 \\
0.52 \\
0.59 \\
0.56 \\
0.59 \\
0.52 \\
0.63 \\
0.59 \\
0.56 \\
0.51 \\
0.41 \\
0.24 \\
0.15^{*} \\
0.19^{*} \\
0.25\end{array}$ & $\begin{array}{l}0.04^{*} \\
0.07^{*} \\
0.25 \\
0.22 \\
0.32 \\
0.25 \\
0.30 \\
0.35 \\
0.36 \\
0.28 \\
0.18 \\
-0.02^{*} \\
-0.13^{*} \\
-0.05^{*} \\
-0.03^{*}\end{array}$ & $\begin{array}{c}-0.48 \\
-0.42 \\
-0.21 \\
-0.19 \\
-0.03^{*} \\
-0.09^{*} \\
-0.13^{*} \\
-0.03^{*} \\
0.09^{*} \\
-0.06^{*} \\
-0.11^{*} \\
-0.26 \\
-0.38 \\
-0.29 \\
-0.29\end{array}$ & $\begin{array}{l}-0.31 \\
-0.26 \\
-0.05^{*} \\
-0.05^{*} \\
0.11^{*} \\
0.02^{*} \\
0.02^{*} \\
0.12^{*} \\
0.19^{*} \\
0.06^{*} \\
0.00^{*} \\
-0.18 \\
-0.29 \\
-0.21 \\
-0.21\end{array}$ \\
\hline All ages & & 0.90 & 0.58 & -0.59 & -0.13 & & 0.91 & 0.64 & $-0 \cdot 49$ & -0.07 \\
\hline
\end{tabular}

${ }^{*}$ No significant correlation with height $(\mathrm{p}>0 \cdot 05){ }^{\mathrm{p}}=$ Age specific exponent derived from slope of $\log$ linear regression for each age group. $\mathbf{p}^{\prime \prime}=$ Exponent derived from slope of $\log$ linear regression for all age groups. 
difference between the two sexes was not, however, observed in our data. The ' $p$ ' for English children rises steadily from 1.82/2.42 (boys/girls) at the age of 4 , to $2 \cdot 89$ (boys and girls) at the age of $11 .{ }^{19}$ This striking age dependency of ' $p$ ' has not been observed in adults $^{20-22}$; it may be attributed to differences in body frame, and patterns of growth as well as to variations in the distribution and deposition of adipose tissue in puberty and adolescence. ${ }^{23-25}$

Body mass index merely reflects body weights among different subjects and may not be the most reliable measure of obesity. ${ }^{26}$ There is no simple and accurate alternative, however, with which to compare nutrional state and diseases associated with obesity in children. Hydrostatic weighting, whole 'body potassium scintillation counting, and electric impedance measurements are indirect estimations of adiposity that are not free from error ${ }^{27-29}$ and are based on ideal but uncertain mathematical assumptions and models. ${ }^{21}$ They are not suitable for routine clinical use or for epidemiological studies. Measurement of skinfold thickness is not easily reproducible. ${ }^{30} 31$ Even among observers rigorously trained in the same anthropometric techniques, the interobserver measurement errors for measurement of skinfold thickness (variance ratios 2.5 to $4.8, \mathrm{p}<0.05$ ) are much greater those for weight and stature (variance ratios 0.67 to $1 \cdot 22, \mathrm{p}>0.05$ ). ${ }^{32}$ Skinfold measurements may account for only as little as $16 \%$ of the variance of fat body mass estimated by underwater weighing ${ }^{33}$ or measurement of potassium $\left({ }^{40} \mathrm{~K}\right) \cdot{ }^{34}$ Thus it is still uncertain which anthropometric measurement or combination of measurements may consistently claim to give a more accurate estimate of body fat. 3135

Inappropriate choice of body mass indices may lead to misleading conclusions about nutritional state, the incidence of obesity, and the epidemiology of diseases associated with obesity, because body mass indices are not interchangeable. ${ }^{8-10}$ Dugdale and Lovell have shown that using $\mathbf{W} / \mathbf{H}$ generated conflicting statistics about obesity in Australian children. ${ }^{10}$ Fixed exponent body mass indices, when applied to the same sets of data, may show the opposite association between obesity and the risk of cancer, ${ }^{8}$ or give inconsistent ranks to obesity among various ethnic groups. ${ }^{9}$ Only the $\mathrm{W} / \mathrm{H}^{\mathrm{p}}$ (that does not correlate with height) provides consistent data. The optimal body mass index must be independent of height, and this has been emphasised ${ }^{111} 16$ and repeatedly stated in cross sectional as well as longitudinal studies of children, ${ }^{25} 3637$ adolescents and adults. ${ }^{3419} 232433$ Himes and Roche, however, have reported a curvilinear correlation between fat thicknesses and stature in children between 6 to 12 weeks old, and in adults, ${ }^{38}$ but their observations are open to criticism. Firstly, the inconsistent patterns of association with respect to sex, age, and measurements (fat thickness at calf and the level of the tenth rib) may be the result of a change in the distribution of body fat during growth. Secondly, the sample of children may not represent those who have much lower linear Pearson correlative coefficients for stature and skin thickness. ${ }^{25} 333637$ The logical assumption that a good body mass index must be independent of measurement of height cannot therefore be confidently refuted.

Comparisons of nutritional state, or the epidemiology of diseases associated with obesity between two or more independent populations using body mass index are legitimate only when a constant exponent ( $p$ ) is referred to the body mass index calculations. ${ }^{20}$ For adults the $\mathrm{W} / \mathrm{H}$ and $\mathrm{W} / \mathrm{H}^{2}$ (which are only relatively correlated with height) have been used as compromise 'fixed exponent' body mass indices for the comparison of obesity or nutritional state between populations known to have different 'p's. 32022 Fixed exponent body mass indices, however, significantly correlate with height in children and therefore their use in interpopulation comparison cannot be justified. The high age dependency of ' $p$ ' clearly suggests that neither the widely used $\mathrm{W} / \mathrm{H}^{2}$ - nor any other body mass index with a constant exponent-is appropriate for comparing nutritional state and obesity between and within groups of children. Age specific 'p's should be used for accurate intrapopulation studies of problems of overweight in children.

The American weight for height standards published by the NCHS have been widely used in North America. These charts were constructed assuming the weight/height relationship was independent of age. ${ }^{39}$ Our study has shown that the age specific 'p's differ materially from that for the whole age group. Accurate weight for height relationships can therefore only be elicited by using age specific centile charts. ${ }^{19}$ Exclusion of older children in the construction of conventional NCHS weight for height charts may reduce but cannot eliminate the confounding influence of age on weight/ height relationship. ${ }^{39}$ These weight for height charts should be used cautiously for accurate estimation of weight for height centile or the assessment of nutritional and obesity state.

When age specific centile charts are not available, or when the age of the child is unknown, the index $\mathrm{W} / \mathrm{H}^{\mathrm{P}}$ expressed as a fraction of the median of a reference population should be used. Cole suggested that $\mathrm{W} / \mathrm{H}^{2}(\mathrm{p}=2)$ is the appropriate body mass index for preschool children and adults. ${ }^{17} 18$ In early puberty, $\mathrm{W} / \mathrm{H}^{2}$ tends to assess tall or physically advanced children as being overweight. This puberty/age bias can be avoided by using $\mathrm{W} / \mathrm{H}^{\mathrm{p}}$ around the age of 11 instead, and the value of ' $p$ ' may be estimated from an exponential mathematical model based on population studies. ${ }^{18}$ There is, however, no consistent trend at puberty for the ' $p$ ' in our series. The exponent cannot be expressed by a simple mathematical model as a function of age and sex. Whether this is because of statistical bias or because there are genuine ethnic differences in body mass index as well as body frame and composition at puberty, remains to be answered.

In summary, age has a strong influence on the exponent of $W / H^{p}$. The age specific $W / H^{p}$ is preferred to fixed exponent body mass indices in nutritional studies in children. For the same 
reason, we warn against the indiscriminate use of conventional NCHS weight for height charts in the interpretation of the nutritional state of children.

We thank Dr SSF Leung, Dr NS Tsoi, Dr KW Lun and the late Dr SY Chu of the University of Hong Kong for their efforts in data collection. We also thank the headmasters of the schools and
kindergartens who allowed us to measure their children, and kindergartens who allowed us to measure their children, and
Mrs Margaret TW Yick Fung and Mrs Ivy BC Yiu Wong for the preparation of the manuscript.

1 Billewicz WZ, Kemsley WFF, Thomson AM. Indices of adiposity. British Foumal of Preventive and Social Medicine 1962;16:183-8.

2 Allen TH, Peng MT, Chen KP, et al. Prediction of blood volume and adiposity in man from body weight and cube of height. Metabolism 1956;5:328-45.

3 Florey CV. The use and interpretation of ponderal and other weight-height ratios in epidemiological studies. $\mathcal{f}$ Chronic Dis 1970;23:93-103.

4 Keys A, Fidanza F, Karvonen MJ, et al. Indices of relative height and obesity. $\mathcal{F}$ Chronic Dis 1972;25:329-43.

5 Khosla T, Lowe CR. Indices of obesity derived from body weight and height. British foumal of Preventive and Social Medicine 1967;21:122-8.

6 Garn SM, Pesick SD. Comparison of the Benn index and other body mass indices in nutritional assessment. $A m \mathcal{F}$ Clin Nutr 1982;36:573-5.

7 Frisancho AR, Flegel PN. Relative merits of old and new indices of body mass with reference to skinfold thickness. Am $\mathcal{F}$ Clin Nutr 1982;36:697-9.

8 Lee J, Kolonel LN. Are body mass indices interchangeable in measuring obesity-disease association? Am $\mathcal{F}$ Public Health 1984;74:376-7.

9 Lee J, Kolonel LN, Hinds MW. The use of an inappropriate weight-height derived index of obesity can produce misweight-height derived index of obesity can
leading results. Int $\mathcal{f}$ Obes 1982;6:233-9.

10 Dugdale AE, Lovell S. Measuring childhood obesity. Lancet 1981 ;ii: 1224 .

11 Benn RT. Some mathematical properties of weight-for-height indices used as measures of adiposity. British fournal of Preventive and Social Medicine 1971;25:42-50.

12 Fung KP, Lau SP, Chow OKW, et al. A survey on growth of Hong Kong children. Hong Kong fournal of Paediatrics 1985;2:105-16.

13 Leung SSF, Lam YM, Lui S, et al. Height, weight and head circumference on Shatin children 3-7 years of age: further evidence for secular changes. Hong Kong fournal of Paediatrics 1987;4:43-51.

14 Tanner JM. Physical growth and development. In: Forfar JO, Arneil GC, eds. Textbook of paediatrics. Edinburgh: Churchill Livingstone, 1984:304-5.

15 Draper NR, Smith H. Applied regression analysis. New York: Wiley, 1981.

16 Dugdale AE. An age-independent anthropometric index of nutritional status. Am $尹$ Clin Nutr 1971;24:174-6.

17 Cole TJ. A critique of the NCHS weight for height standard. Hum Biol 1985;57:183-96.

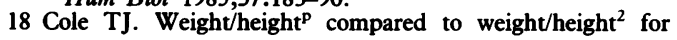

assessing adiposity in childhood: influence of age and bone age on p during puberty. Ann Hum Biol 1986;13:433-51. 19 Chinn S, Morris RW. Standards of weight-for-height for English children from age 5.0 to 11.0 years. Ann Hum Biol 1980;5:457-71.

20 Lee J, Kolonel LN, Hinds MW. Relative merits of weightcorrected-for-height indices. Am $\mathcal{F}$ Clin Nutr 1981;34:

21 Womersley J, Durnin JVGA. A comparison of the skinfold method with extent of 'overweight' and various weightheight relationships in the assessment of obesity. $B r \mathcal{F}$ Nut 1977;38:271-84.

22 Goldbourt U, Medalie JH. Weight-height indices: choice of the most suitable index and its association with selected variables among 10000 adult males of heterogeneous origin. British foumal of Preventive and Social Medicine 1974;28:116-26.

23 Cronk CE, Roche AF. Race- and sex-specific reference data for triceps and subscapular skinfolds and weight/stature. Am $\mathcal{F}$ Clin Nutr 1982;35:347-54.

24 Parizkova J. Growth and growth velocity of lean body mass and fat in adolescent boys. Pediatr Res 1976;10:647-50.

25 Maresh M. Changes in tissue widths during growth. Am 7 Dis Child 1966;111:142-55.

26 Garn SM, Leonard WR, Hawthorne VM. Three limitations of the body mass index. Am $\mathcal{F}$ Clin Nutr 1986;44:996-7.

27 Burmeister W. Potassium-40 content as a basis for the calculation of body cell mass in man. Science 1965;148:1336-7.

28 Garrow JS, Stalley S, Diethelm R, et al. A new method for measurement the body density of obese adults. $\mathrm{Br} \mathcal{F}$ Nutr 1979;42:173-83.

29 Hodgdon JA, Fitzgerald PI. Validity of impedance predictions at various levels of fatness. Hum Biol 1987;59:281-98.

30 Johnston FE, Hamill PVV, Lemeshow S. Skinfold thickness of youths 12-17 years, United States. Department of Health, Education, and Welfare Publication (Health Resources Administration) No 74-1614. Washington DC: National Center for Health Statistics, 1974.

31 Owen GM. Mesurement, recording, and assessment of skinfold thickness in childhood and adolescence: report of a fold thickness in childhood and adolescence: report

32 Bennett KA, Osborne RH. Interobserver measurement reliability in anthropometry. Hum Biol 1986;58:751-9.

33 Seltzer CC, Goldman RF, Mayer J. The triceps skinfold as a predictive measure of body density and body fat in obese
a adolescents girls. Pediatrics 1965;36:212-8.

34 Dugdale AE, Griffiths $M$. Estimating fat body mass from anthropometric data. Am $\mathcal{F}$ Clin Nutr 1979;32:2400-3.

35 Roche AF, Siervogel RM, Chumlea WC, et al. Grading body fatness from limited anthropometric data. Am $\mathcal{F}$ Clin Nutr 1981;34:2831-8.

36 Rolland-Cachera MF, Sempe M, Guilloud-Bataille MG, et al. Adiposity indices in children. Am 7 Clin Nutr 1982;36: 178-84.

37 Micozzi MS, Albanes D, Jones Y, et al. Correlations of body mass indices with weight, stature, and body composition in men and women in NHANES I and II. Am $\mathcal{F}$ Clin Nutr 1986;44:725-31.

38 Himes JH, Roche AF. Subcutaneous fatness and stature: relationship from infancy to adulthood. Hum Biol 1986;58: 737-50.

39 Hamill PVV, Drizd TA, Johnson CL, et al. Physical growth: National Center for Health Statistics percentiles. A $m \mathcal{F}$ Clin Nutr 1979;32:607-29. 